Aisyah Journal of Informatics and Electrical Engineering Universitas Aisyah Pringsewu

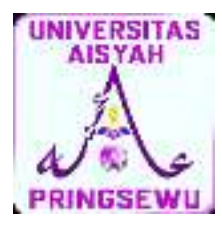

Journal Homepage http://jti.aisyahuniversity.ac.id/index.php/AJIEE

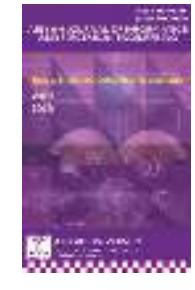

\title{
PERANCANGAN SISTEM INFORMASI PENERIMAAN PESERTA DIDIK BARU BERBASIS WEB (STUDI KASUS : MTsN 2 KOTA TANGERANG)
}

\author{
Alfredo Pasaribu ${ }^{1}$, Agustinus Eko Setiawan ${ }^{2}$, Nur Atika ${ }^{3}$ \\ ${ }^{1}$ Program Studi Sistem Informasi, STMIK Kuwera \\ ${ }^{2,3}$ Program Studi Teknik Informatika, Fakultas Teknologi dan Informatika \\ ${ }^{1}$ STMIK Kuwera \\ ${ }^{2}$ Universitas Aisyah Pringsewu

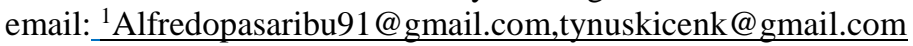

\begin{abstract}
Abstrak
Untuk mendukung terlaksananya peraturan pemerintah terkait Penerimaan Peserta Didik Baru (PPDB) dengan baik, diperlukan pengembangan sistem pada MTsN 2 Kota Tangerang memerlukan yang selama ini berjalan secara manual. Hal ini mengakibatkan calon siswa seringkali mengalami kendala seperti kesulitan mendapatkan informasi untuk melakukan proses pendaftaran. Proses administrasi juga cenderung lambat karena data belum terintegrasi dan terkelola dengan baik dan hanya mengandalkan data yang tersimpan dalam Excel. Proses ini juga masih menggunakan arsip dalam bentuk fisik yang rentan mengalami kerusakan atau bahkan hilang dan mengandalkan data yang tersimpan dalam Excel aja. Untuk dapat mengatasi permasalahan yang terjadi pada pendaftaran siswa baru di MTsN 2 Kota Tangerang dibuatlah perancangan aplikasi Sistem Informasi Penerimaan Peserta Didik Baru Berbasis Web. Metode yang digunakan untuk pembangunan sistem informasi menggunakan Model Prototype dengan pendekatan sistem berorientasi objek yang dimodelkan menggunakan UML (Unified Modelling Language). Hasil akhir dari perancangan sistem PPDB online ini adalah adanya sebuah aplikasi yang dapat memberi kemudahan akses informasi dan proses pendaftaran sehingga proses administrasi penerimaan siswa baru menjadi lebih efektif dan efisisen.
\end{abstract}

Kata Kunci : sistem informasi, penerimaan peserta didik baru, prototype, UML, web 


\section{PENDAHULUAN}

\subsection{Latar Belakang Masalah}

Sistem penerimaan peserta didik baru yang berjalan pada MTsN 2 Kota Tangerang, saat ini masih dilakukan secara manual. Untuk mengetahui informasi pendaftaran, melakukan proses pendaftaran hingga melihat pengumuman hasil seleksi, calon siswa harus datang langsung ke sekolah.

Hal tersebut menimbulkan beberapa permasalahan, antara lain sering terjadinya kesalahan dalam pengolahan data karena banyaknya data calon siswa pendaftar yang harus diolah sementara tenaga panitia penyelenggara sangat terbatas, sulitnya pencarian data siswa pendaftar karena data dalam bentuk tumpukan formulir, masih menggunakan arsip dalam bentuk fisik sehingga rentan mengalami kerusakan atau bahkan hilang, tidak efisiennya waktu dalam proses penyeleksian dengan melihat dan mengecek satu per satu persyaratan formulir pendaftaran calon siswa, dan dikarenakan calon siswa harus datang ke sekolah maka terjadi penumpukan antrian dalam lingkungan sekolah. Antrian panjang dan membeludak di MTSn 2 Kota Tangerang sangat memprihatinkan pihak panitia penyelenggara karena membuat orangtua calon siswa yang sudah lama dan lelah menunggu ternyata tidak bisa mendaftar akibat formulir habis (kuota penuh) atau tidak membawa syarat dokumen yang lengkap. Sehingga panitia dinilai lambat dalam melakukan sosialisasi atau membuat pengumuman seperti syarat kelengkapan dokumen, hasil verifikasi kelulusan kepada calon siswa baru. Hal ini membuat pihak sekolah MTSn 2 Kota Tangerang sadar akan kebutuhan sistem informasi penerimaan peserta didik baru menjadi hal yang harus dipertimbangkan.

\subsection{Rumusan Masalah}

Berdasarkan uraian di atas, dapat disimpulkan permasalahan dalam penelitian ini adalah:

Bagaimana merancang sistem informasi penerimaan peserta didik baru berbasis Web pada MTsN 2 Kota Tangerang?

\subsection{Batasan Masalah}

Agar penelitian tidak meluas dan terfokus pada tujuan penelitian, maka penulis membatasi masalah penelitian, yaitu:

1. Perancangan sistem informasi berbasis web ini tidak membahas mengenai proses pembayaran administrasi pendaftaran sehingga tidak ada kaitannya dengan bagian keuangan.

2. Sistem informasi berbasis web ini tidak menyediakan fasilitas untuk melakukan tes secara online atau ujian online.

3. Sistem informasi berbasis web ini tidak membahas mengenai proses pemberian nilai ujian seleksi atau hanya sampai pada proses pengumuman status kelulusan peserta didik baru saja.

\subsection{Tujuan Penelitian}

Tujuan yang ingin dicapai penulis dalam penelitian ini adalah:

1. Melakukan analisis dan perancangan sistem informasi penerimaan peserta didik baru berbasis web di MTsN 2 Kota Tangerang agar calon siswa dipermudah dalam mengakses informasi dan proses pendaftaran.

2. Merancang dan membuat sistem informasi berbasis web yang dapat mengatasi permasalahan baik dari sisi calon siswa maupun pihak panitia penyelenggara. 


\subsection{Manfaat Penelitian}

Adapun manfaat yang ingin diperoleh dari penelitian ini antara lain:

1. Pihak panitia penerimaan didik baru terbantu dalam melakukan tugas administrasi pendaftaran calon siswa baru.

2. Orangtua dan calon siswa dipermudah untuk mendapat informasi serta pendaftaran dalam penerimaan peserta didik baru.

3. Untuk mengimplementasikan dan mengembangkan ilmu pengetahuan bagi penulis.

\section{LANDASAN TEORI}

\subsection{Perancangan}

Perancangan adalah suatu kegiatan yang memiliki tujuan untuk mendesign sistem baru yang dapat menyelesaikan masalah-masalah yang dihadapi perusahaan yang diperoleh dari pemilihan alternatif sistem yang terbaik. ${ }^{\mathrm{i}}$

\subsection{Sistem}

Sistem sebagai suatu komponen atau variabel yang terorganisir, saling berinteraksi, saling bergantung satu samalain dan terpadu. ${ }^{\text {ii }}$

\subsection{Informasi}

Informasi merupakan hasil pengolahan data sehingga menjadi bentuk yang penting bagi penerimanya dan mempunyai kegunaan sebagai dasar dalam pengambilan keputusan yang dapat dirasakan akibatnya secara langsung saat itu juga atau secara tidak langsung pada saat mendatang. ${ }^{\text {iii }}$

\subsection{Sistem Informasi}

Sistem Informasi adalah sekumpulan elemen yang bekerja secara bersama- sama baik secara manual ataupun berbasis computer dalam melaksanakan pengolahan data yang berupa pengumpulan, penyimpanan, pemrosesan data untuk menghasilkan informasi yang bermakna dan berguna bagi proses pengambilan keputusan. iv

\subsection{Penerimaan Siswa baru}

Berdasarkan peraturan bersama antara Menteri Pendidikan Nasional dan Menteri Agama Nomor 04/VI/PB/2011 MA/111/2011 tentang penerimaan siswa baru pada Taman Kanak - Kanak / Raudhatul Athfal / Bustanul Athfal dan Sekolah/Madrasah, penerimaan peserta didik baru adalah penerimaan peserta didik baru TK/RA/BA dan sekolah / madrasah yang dilaksanakan pada awal tahun ajaran baru. Penerimaan peserta didik baru pada TK/RA/BA dan sekolah/madrasah harus

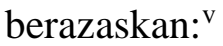

1. Obyektivitas, artinya penerimaan peserta didik baru, baik peserta didik baru maupun pindahan harus memenuhi ketentuan umum yang diatur di dalam Peraturan Bersama Menteri ini;

2. Transparansi, artinya pelaksanaan penerimaan peserta didik baru bersifat terbuka dan dapat diketahui oleh masyarakat termasuk orang tua peserta didik baru, untuk menghindari segala penyimpangan yang mungkin terjadi;

3. Akuntabilitas, artinya adalah penerimaan peserta didik baru dapat dipertanggungjawabkan kepada masyarakat, baik prosedur maupun hasilnya; dan

4. Tidak diskriminatif, artinya setiap warga negara yang berusia sekolah dapat 
mengikuti program pendidikan di wilayah Negara Kesatuan Republik Indonesia tanpa membedakan suku, daerah asal, agama, golongan, dan status sosial (kemampuan finansial).

\section{METODE}

Untuk metode dalam pembangunan perangkat lunak sistem informasi ini menggunakan model Prototype, yaitu model metodologi pengembangan perangkat lunak yang menitik beratkan pada pendekatan aspek desain, fungsi dan user-interface. Berikut gambar pengembangan perangkat lunak Model Prototype dapat dilihat pada gambar 1.

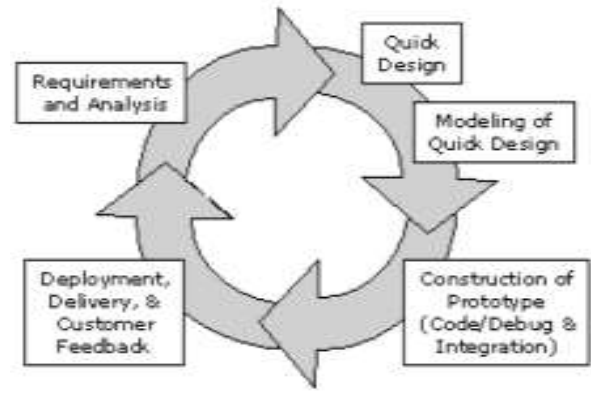

Gambar 1. Pengembangan Perangkat Lunak Model Prototype. ${ }^{\text {vi }}$

\section{PEMBAHASAN}

\subsection{Analisis Prosedur yang Sedang Berjalan}

Analisis prosedur yang sedang berjalan akan menguraikan secara sistematis mengenai aktivitas yang terjadi pada prosedur penerimaan peserta didik baru (PPDB) yang sedang berjalan di MTsN 2 Kota Tangerang, yakni sebagai berikut:

1. Peserta PPDB datang ke lokasi MTsN 2 Kota Tangerang untuk melakukan pendaftaran,

2. Peserta PPDB mengambil formulir dari panitia dan mengisi formulir serta melampirkan rincian berkas sesuai syarat dan ketentuan. Jika formulir sudah terisi lengkap dan dilampirkan berkas yang dibutuhkan maka diserahkan ke pihak panitia untuk diverifikasi.

3. Peserta PPDB yang dinyatakan lolos tahap verifikasi administrasi akan diberi tanda bukti pendaftaran dan informasi untuk melaksanakan serangkaian ujian seleksi oleh panitia.

4. Peserta PPDB mengikuti ujian seleksi masuk di MTsN 2 Kota Tangerang pada waktu dan ruangan yang telah ditentukan.

5. Setelah mengikuti ujian seleksi masuk, hasil seleksi akan diumumkan melalui telepon, pesan singkat dan papan pengumuman sekolah.

6. Peserta PPDB yang dinyatakan lulus tes masuk, harus melakukan daftar ulang pada waktu yang telah ditentukan, jika tidak maka akan dianggap mengundurkan diri.

\subsection{Evaluasi Sistem Berjalan}

Setelah mengamati dan menganalisis terhadap prosedur penerimaan peserta didik baru yang berjalan di MTsN 2 Kota Tangerang, maka dapat diketahui kelemahan - kelemahan yang terjadi.

Tabel 1. Kelemahan Sistem Berjalan

\begin{tabular}{|c|c|c|c|c|}
\hline $\mathrm{N}$ & Objek & Faktor & Masalah & Solusi \\
\hline 1 & $\begin{array}{l}\text { Data } \\
\text { calon } \\
\text { siswa/pes } \\
\text { erta } \\
\text { PPDB }\end{array}$ & $\begin{array}{l}\text { Biodata } \\
\text { calon } \\
\text { siswa } \\
\text { berupa } \\
\text { formulir } \\
\text { kertas }\end{array}$ & $\begin{array}{l}\text { 1. Data } \\
\text { sulit } \\
\text { dicar } \\
\text { i atau } \\
\text { dite } \\
\text { muka } \\
\text { n } \\
\text { saat } \\
\text { dibut } \\
\text { uhka } \\
\text { n; } \\
\text { 2. Data } \\
\text { relati } \\
\text { f } \\
\text { muda } \\
\text { h }\end{array}$ & $\begin{array}{l}\text { Membuat } \\
\text { aplikasi } \\
\text { yang dapat } \\
\text { mengintegr } \\
\text { asikan data } \\
\text { sehingga } \\
\text { aman dan } \\
\text { mudah } \\
\text { untuk dicari } \\
\text { ketika } \\
\text { dibutuhkan }\end{array}$ \\
\hline
\end{tabular}

32 


\begin{tabular}{|c|c|c|c|c|}
\hline & & & $\begin{array}{l}\text { rusak } \\
\text { atau } \\
\text { hilan } \\
\text { g }\end{array}$ & \\
\hline 2 & $\begin{array}{l}\text { Pengumu } \\
\text { man dan } \\
\text { pemberita } \\
\text { huan } \\
\text { informasi } \\
\text { pendaftar } \\
\text { an }\end{array}$ & $\begin{array}{l}\text { Pemberi } \\
\text { an } \\
\text { informas } \\
\text { i masih } \\
\text { melalui } \\
\text { telepon, } \\
\text { pesan } \\
\text { singkat } \\
\text { atau } \\
\text { terpajan } \\
\text { g di } \\
\text { papan } \\
\text { pengum } \\
\text { uman } \\
\text { sekolah }\end{array}$ & $\begin{array}{l}\text { Informas } \\
\text { i yang } \\
\text { sampai } \\
\text { kepada } \\
\text { calon } \\
\text { siswa } \\
\text { terkadan } \\
\text { g atau } \\
\text { terkesan } \\
\text { lambat }\end{array}$ & $\begin{array}{l}\text { Membuat } \\
\text { aplikasi } \\
\text { yang dapat } \\
\text { memudahk } \\
\text { an dan } \\
\text { mempercep } \\
\text { at dalam } \\
\text { memberika } \\
\text { n informasi } \\
\text { pendaftaran } \\
\text { pengumum } \\
\text { an } \\
\text { kelulusan }\end{array}$ \\
\hline 3 & Laporan & $\begin{array}{l}\text { Laporan } \\
\text { masih } \\
\text { direkap } \\
\text { secara } \\
\text { manual }\end{array}$ & $\begin{array}{l}\text { Kesulitan } \\
\text { dalam } \\
\text { melakuk } \\
\text { an rekap } \\
\text { laporan } \\
\text { dan } \\
\text { keterlam } \\
\text { batan } \\
\text { informasi } \\
\text { yang } \\
\text { dihasilka } \\
\text { n }\end{array}$ & $\begin{array}{l}\text { Pembuatan } \\
\text { aplikasi } \\
\text { yang efektif } \\
\text { untuk } \\
\text { mengolah } \\
\text { data dengan } \\
\text { cepat dan } \\
\text { mudah } \\
\text { untuk } \\
\text { dijadikan } \\
\text { laporan }\end{array}$ \\
\hline
\end{tabular}

\subsection{Perancangan Sistem}

UML adalah himpunan struktur dan teknik untuk pemodelan dan desain program berorientasi objek (OOP) serta aplikasinya ${ }^{\text {vii }}$. Dengan menggunakan UML kita dapat membuat model untuk semua jenis aplikasi piranti lunak, dimana aplikasi tersebut dapat berjalan pada piranti keras, sistem operasi dan jaringan apapun, serta di itulis dalam bahasa pemrograman apapun.

\subsubsection{Use Case Diagram}

Use case diagram menggambarkan interaksi antar objek di dalam dan di sekitar sistem (termasuk pengguna, display, dan sebagainya) berupa pesan yang digambarkan terhadap waktu. Use case diagram biasa digunakan untuk menggambarkan skenario atau rangkaian langkah yang dilakukan sebagai respons dari sebuah event untuk menghasilkan output tertentu. ${ }^{\text {vii }}$

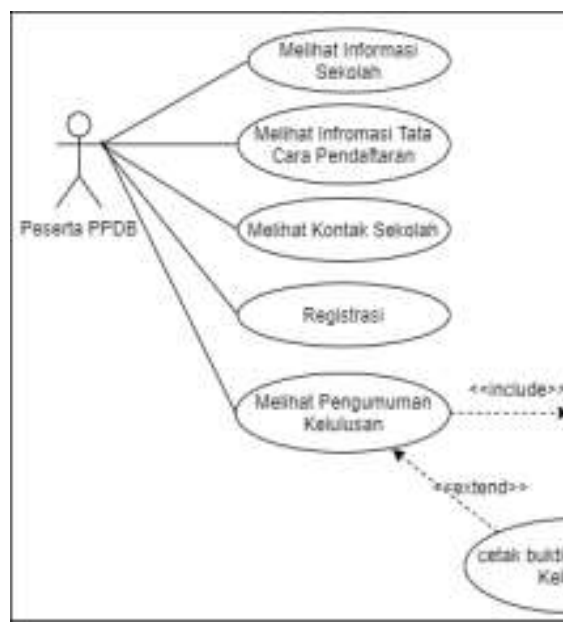

Gambar 1. Use case Peserta PPDB

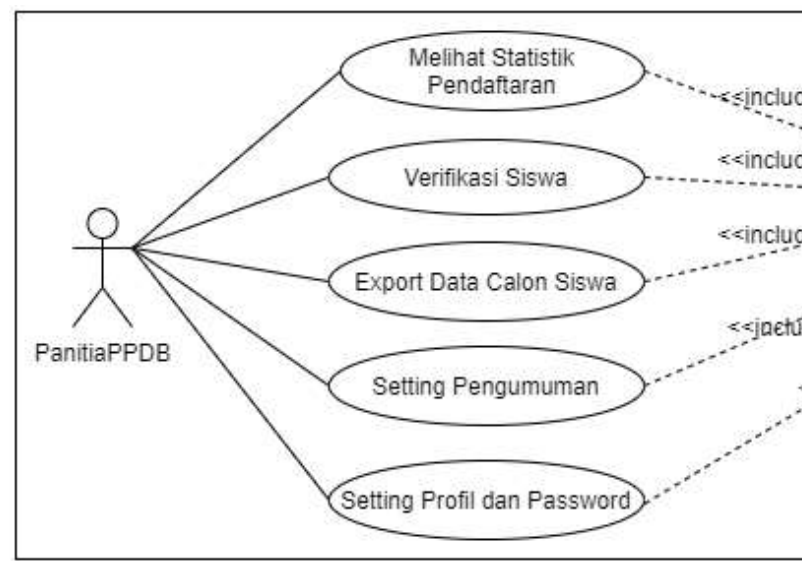

Gambar 2. Use case Panitia PPDB

\subsubsection{Activity Diagram}

Activity diagram adalah teknik untuk mendiskripsikan logika prosedural, proses bisnis dan aliran kerja dalam banyak kasus.

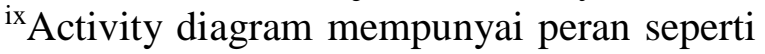
halnya flowchart, akan tetapi perbedaannya dengan flowchart adalah activity diagram bisa mendukung perilaku paralel sedangkan flowchart tidak bisa.

Activity diagram menggambarkan proses bisnis dan urutan aktivitas dalam sebuah proses business modeling untuk memperlihatkan urutan aktifitas proses bisnis. Struktur diagram ini mirip flowchart 
atau Data Flow Diagram pada perancangan terstruktur. Sangat bermanfaat apabila kita membuat diagram ini terlebih dahulu dalam memodelkan sebuah proses untuk membantu memahami proses secara keseluruhan. Activity diagram dibuat berdasarkan sebuah atau beberapa use case pada use case diagram.

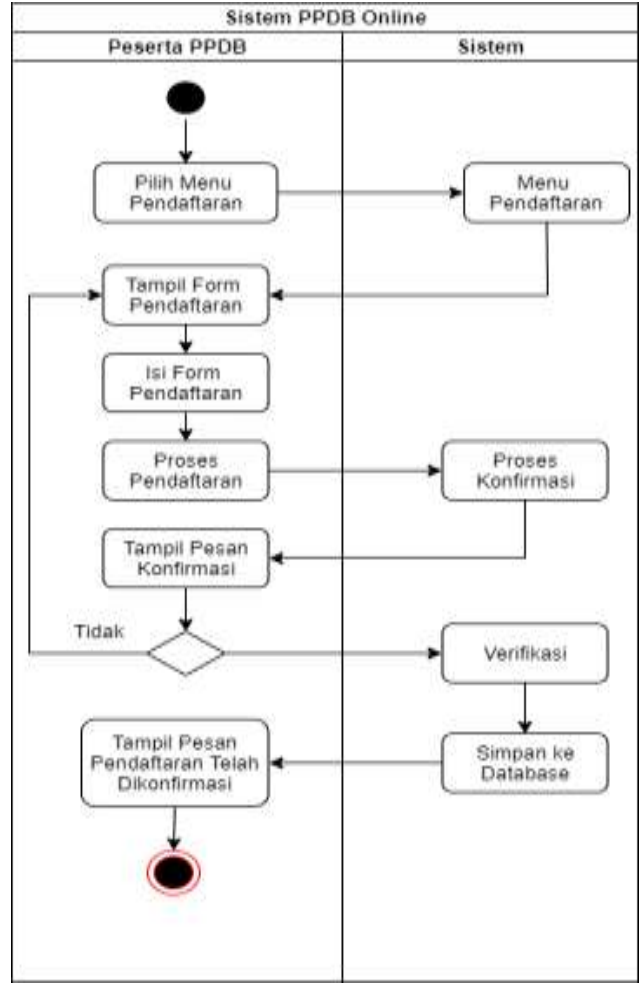

Gambar 2. Activity Diagram Peserta PPDB: Melakukan Pendaftaran

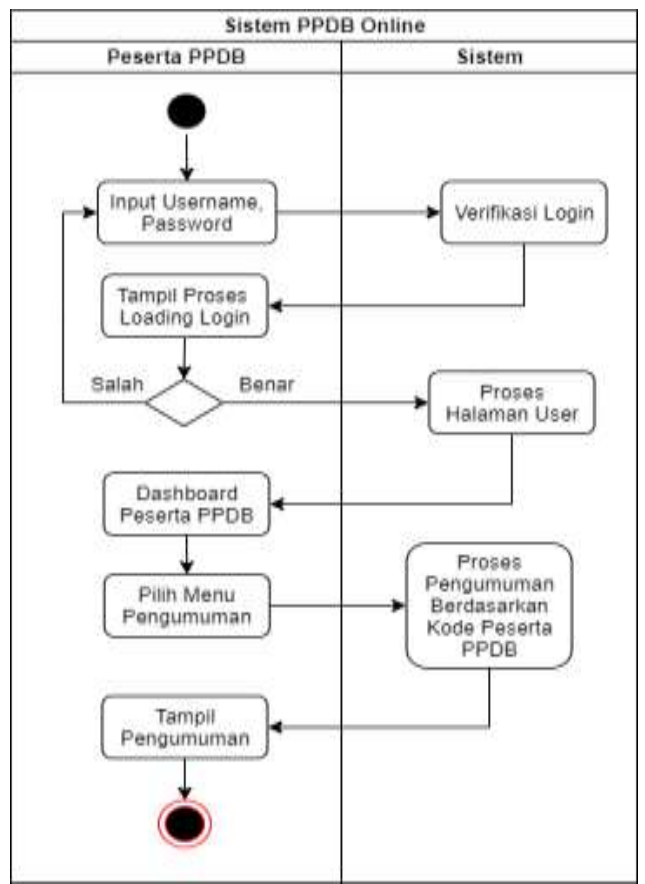

Gambar 3. Activity Diagram Peserta PPDB: Melihat Pengumuman

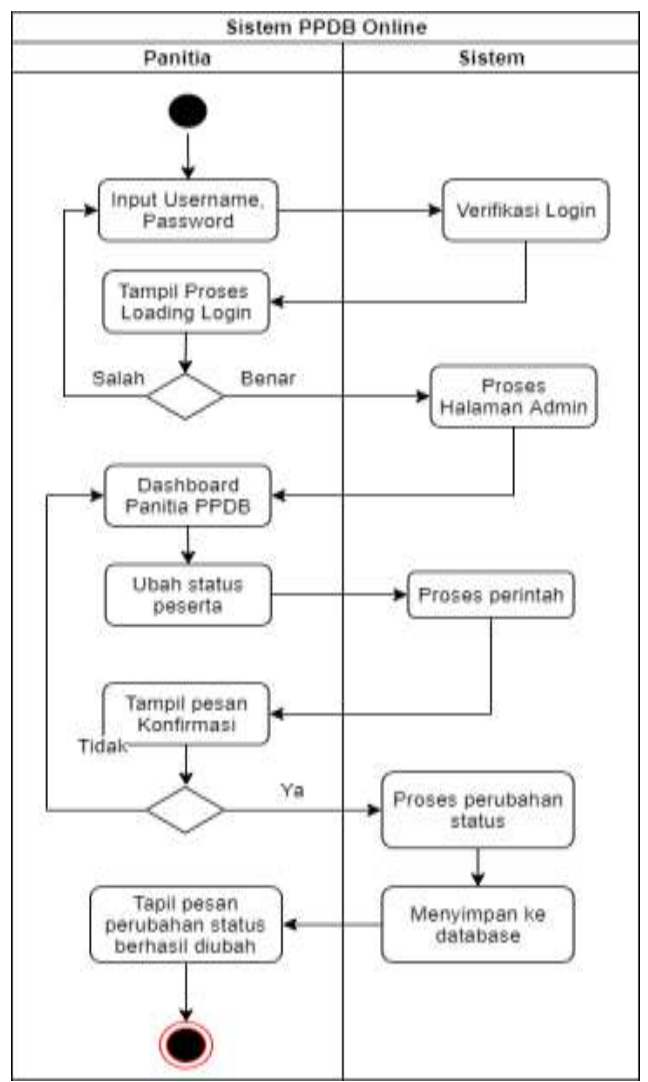

Gambar 4. Activity Diagram Panitia PPDB: Ubah Status Peserta 


\subsubsection{Perancangan Basis Data}

Perancangan basis data adalah proses untuk menentukan isi dan pengaturan data yang dibutuhkan untuk mendukung perancangan sistem. Berikut adalah perancangan basis data dari sistem informasi penerimaan peserta didik baru berbasis web di MTsN 2 Kota Tangerang.

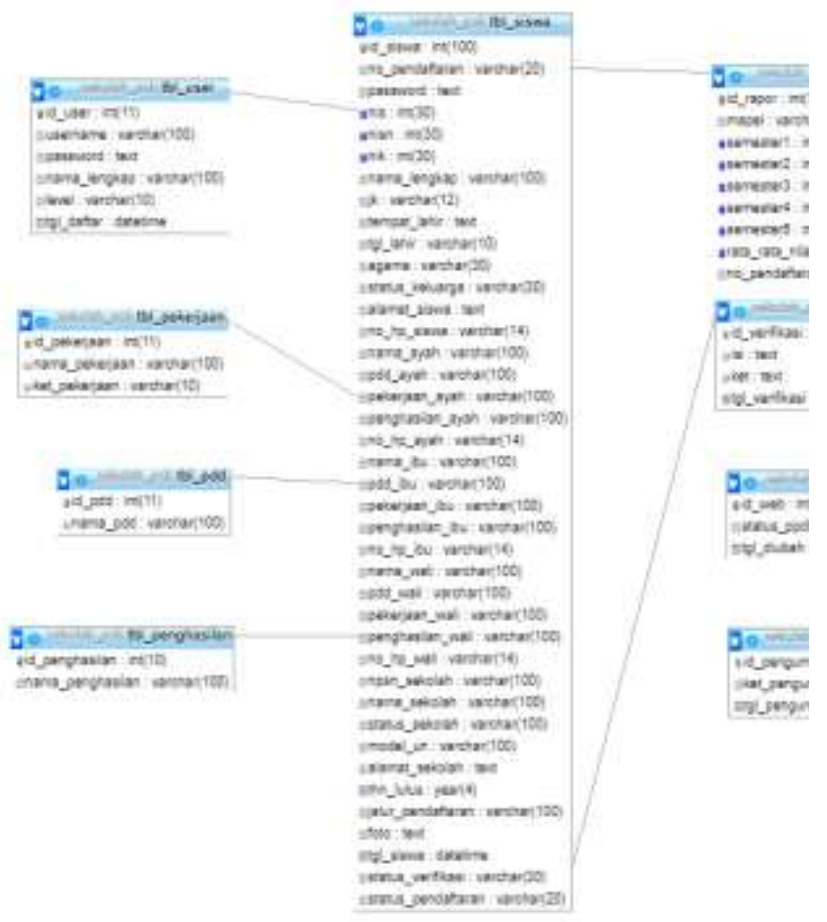

Gambar 5. Tabel fisik perancangan basis data PPDB

\subsubsection{Perancangan Antarmuka}

Perancangan antar muka adalah perancangan tampilan setiap halaman dari sebuah sistem informasi. Perancangan antarmuka dalam penelitian ini dibagi menjadi 3 bagian yakni tampilan antar muka yang dapat diakses oleh Peserta PPDB dan Admin.

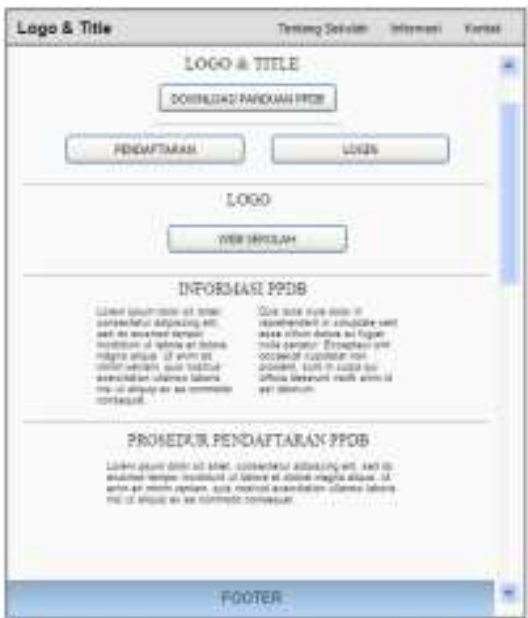

Gambar 6. Desain tampilan depan untuk peserta PPDB sebelum login

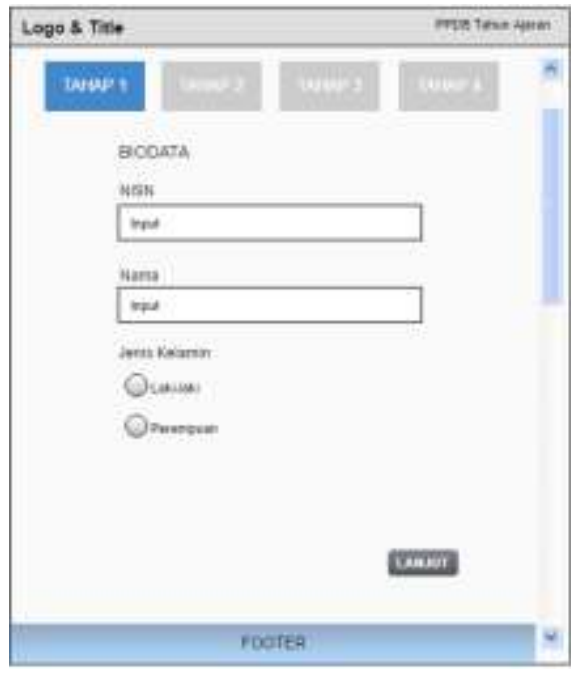

Gambar 7. Desain tampilan form pendaftaran untuk peserta PPDB

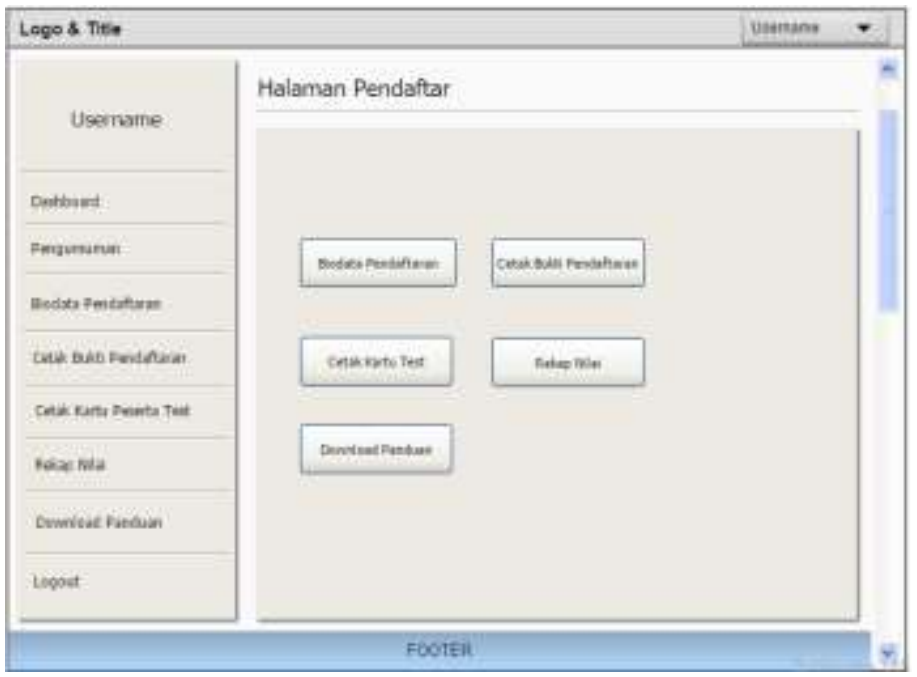




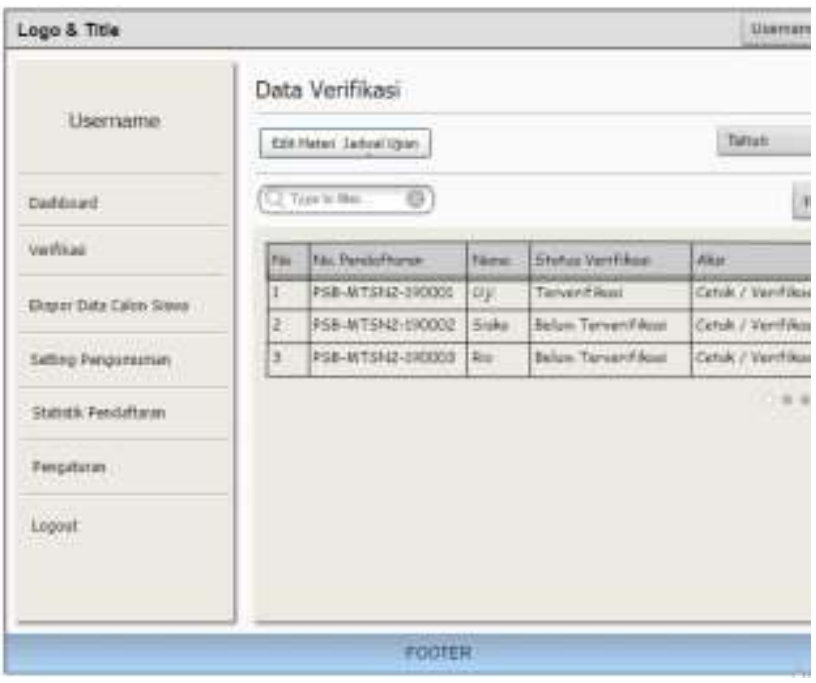

Gambar 9. Desain tampilan verifikasi Panitia PPDB

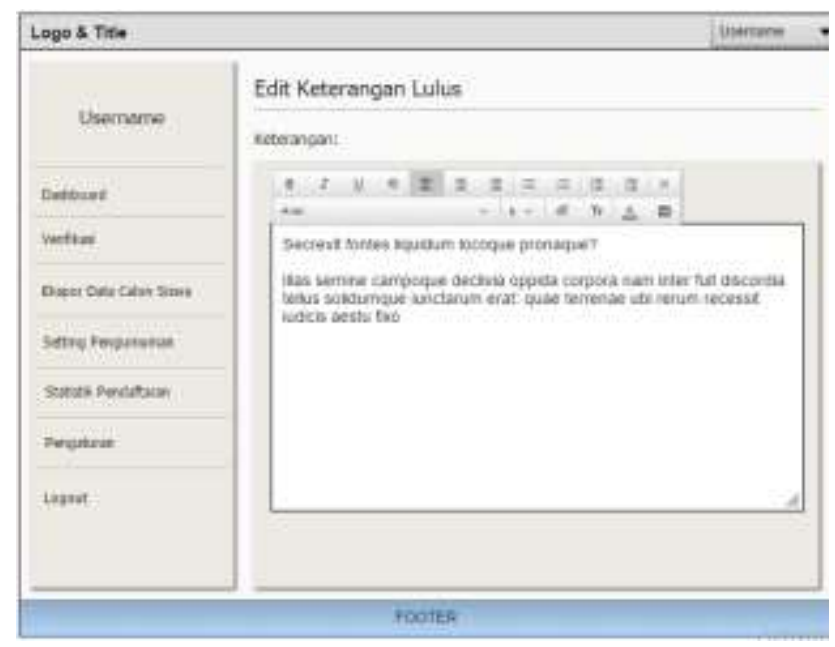

Gambar 10. Desain tampilan edit pengumuman oleh Panitia PPDB

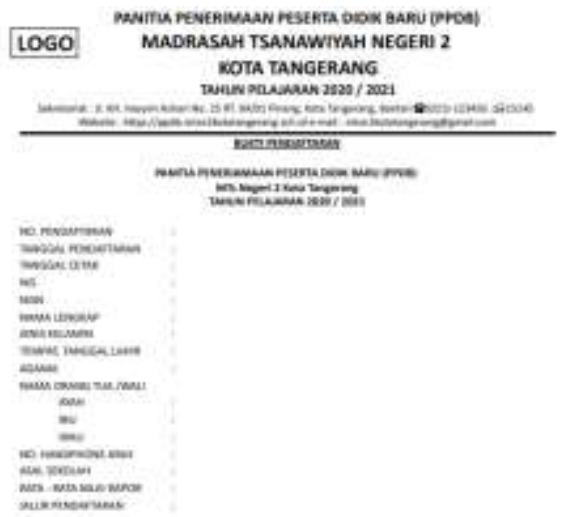

Gambar 10. Desain tampilan output pendaftaran Peserta PPDB

\subsection{Implementasi Program}

Adapun implementasi dari perancangan antarmuka aplikasi yang telah dirancang dapat dilihat sebagai berikut :

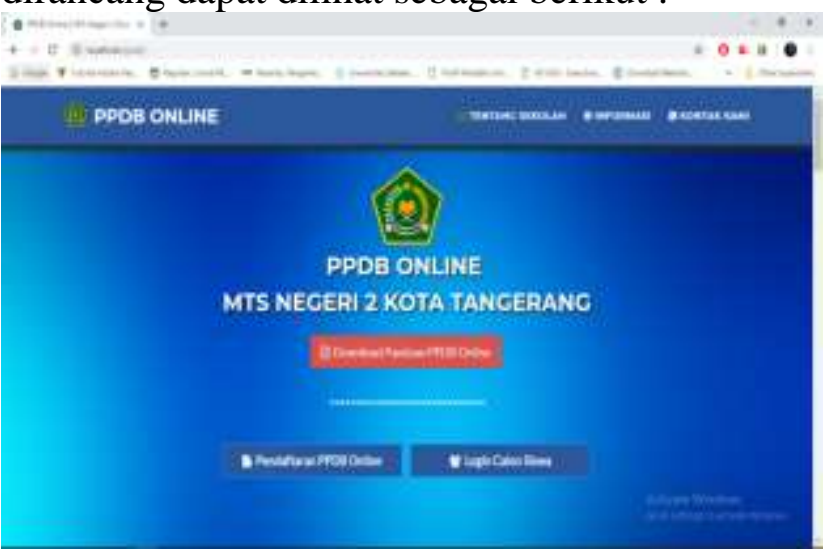

Gambar 11. Tampilan depan peserta PPDB sebelum login

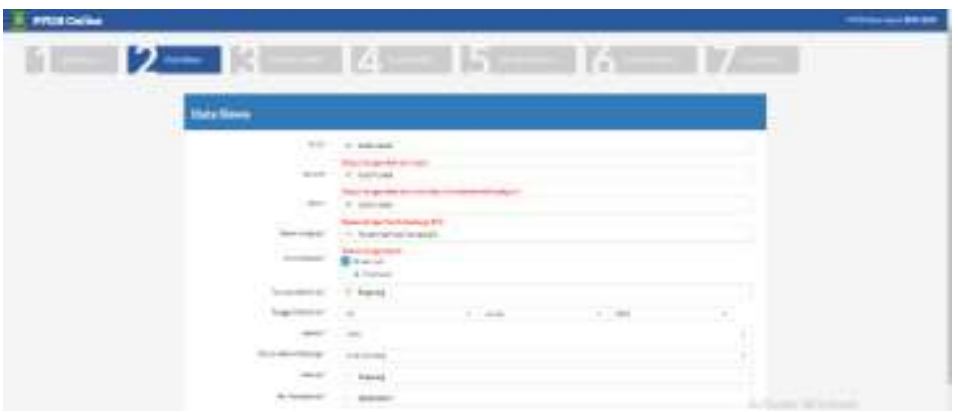

Gambar 12. Tampilan form pendaftaran peserta PPDB

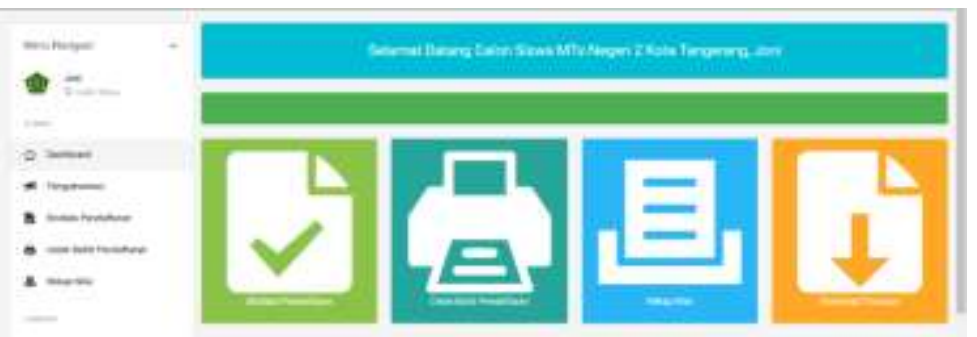

Gambar 13. Tampilan halaman peserta PPDB 


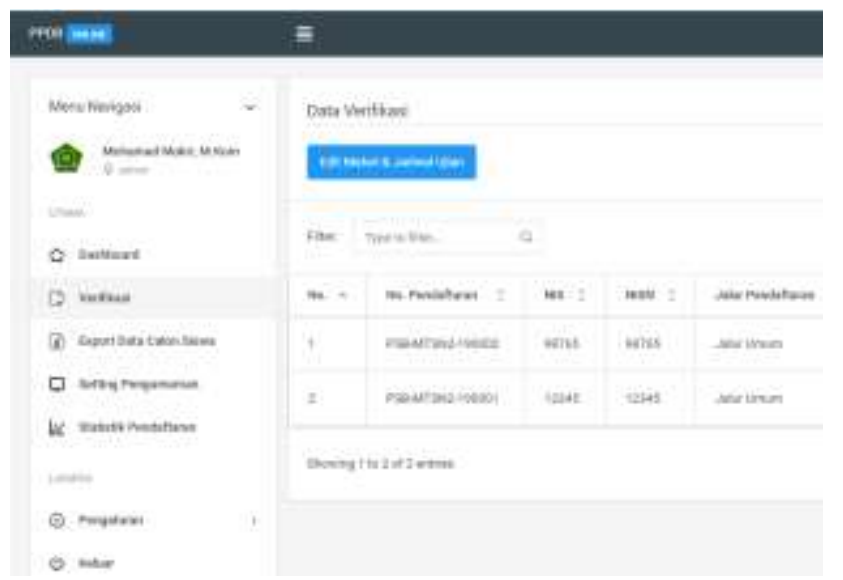

Gambar 14. Tampilan halaman panitia PPDB untuk verifikasi peserta

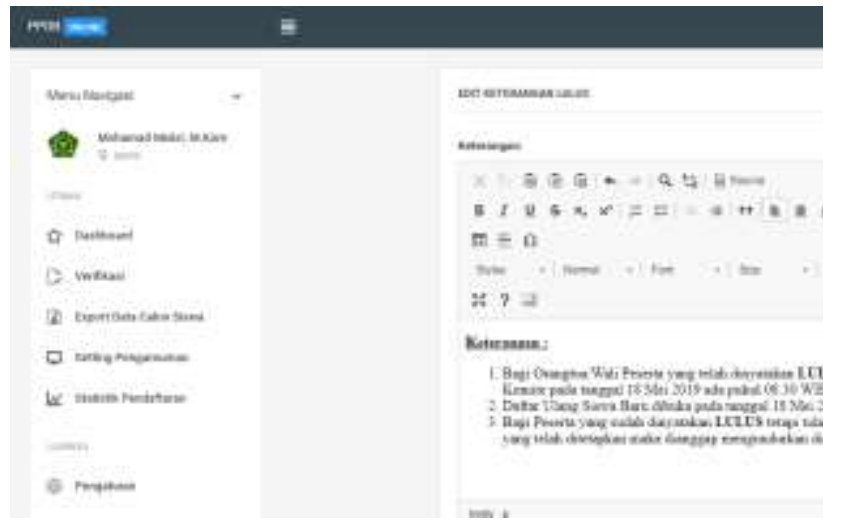

Gambar 15. Tampilan halaman panitia PPDB untuk edit pengumuman

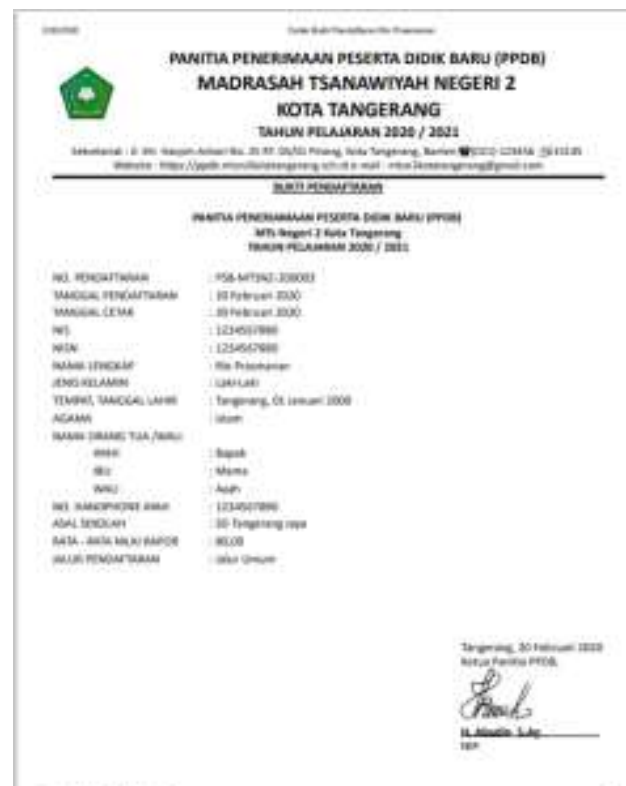

Gambar 16. Tampilan output bukti pendaftaran peserta PPDB

\section{Kesimpulan}

Berdasarkan analisis, perancangan yang telah dilakukan dalam pembuatan sistem informasi PPDB di MTsN 2 Kota Tangerang ini maka dapat diambil beberapa kesimpulan sebagai berikut:

1. Sistem informasi PPDB ini mampu mempermudah akses informasi dan spendaftaran bagi calon siswa.

2. Sistem informasi PPDB ini mampu mengatasi pengolahan data calon siswa menjadi lebih baik karena tersimpan dalam suatu basis data yang terintegrasi.

3. Proses administrasi penerimaan siswa baru menjadi lebih efektif dan efisisen sehingga memberi kemudahan bagi para panitia PPDB di MTsN 2 Kota Tangerang. 


\section{DAFTAR PUSTAKA}

i Al-Bahra. 2005. Analisis dan Desain Sistem Informasi. Graha Ilmu. Yogyakarta. ii Al-Bahra. 2005. Analisis dan Desain Sistem Informasi. Graha Ilmu. Yogyakarta

iii Tantra, Rudy, 2012. Manajemen Proyek Sistem Informasi: CV. Andi Offset, Yogyakarta.

iv Tantra, Rudy, 2012. Manajemen Proyek Sistem Informasi: CV. Andi Offset, Yogyakarta.

v Peraturan Bersama Antara Menteri Pendidikan Nasional dan Menteri Agama Nomor 04/VI/PB/2011 - MA/111/2011 vi Pressman, Roger S. 2002. Rekayasa Perangkat Lunak. Andi. Yogyakarta. vii Kroenke, David. 2005. Database Processing Jilid 1 Edisi 9. Erlangga. Jakarta viii Munawar. 2005. "Pemodelan Visual Dengan UML". Graha Ilmu, Yogyakarta ix Munawar. 2005. "Pemodelan Visual Dengan UML”. Graha Ilmu, Yogyakarta ${ }^{x}$ N. Aminudin, "LANGKAH - LANGKAH TAKTIS PENGEMBANGAN E-GOVERNMENT UNTUK PEMERINTAHAN DAERAH (PEMDA) KABUPATEN PRINGSEWU," Aisyah J. Informatics Electr. Eng., pp. 89-95, 2019. Retrieved From http://jitiaisyahuniversity.ac.id/index.php/AJIEE/artic le/view/LANGKAHLANGKAHTAKTIS/LANGKA HLANGKAHTAKTIS 